Отримано: 29.05.2019 p.

Прорецензовано: 12.06.2019 p.

Прийнято до друку: 10.07.2019 p.

e-mail: kulakovsky@ukr.net

DOI: $10.25264 / 2409-6806-2019-28-20-31$
Кулаковський П. Новгород-сіверська гродська канцелярія: персональний склад. Наукові записки Наиіонального університету «Острозька академія». Серія «Історичні науки». Острог, 2019. Вип. 28. С. 20-31.

\title{
Петро Кулаковський
}

УДК 94(477.51) «1636/1648»: 651.45

\section{НОВГОРОД-СІВЕРСЬКА ГРОДСЬКА КАНЦЕЛЯРІЯ: ПЕРСОНАЛЬНИЙ СКЛАД}

У статті проаналізовано персональний склад новгород-сіверської тродської канцелярії протягом часу ії функціонування (1636-1648 рр.). Встановлено походження ї̈ урядників і нижчого персоналу, простежено їх кар'єру в межах канцелярії та в шляхетському соиіумі. Доведено, щзо всі постійні працівники канщелярії належали до клієнтели місиевих старост - Олександра і Яна Пісочинських. За службу в канщелярії вони отримували від патронів земельні маєтності на правах володіння або оренди. Простежено кадровий перетік нижчих працівників канцелярій украӥнських воєводств Речі Посполитої до новгород-сіверської тродської канщелярії.

Ключові слова: трод, канцелярія, персонал, староста, Новгород-Сіверський.

\section{Petro Kulakovskyi}

\section{CASTLE CHANCERY OF NOVHOROD-SIVERSKYI: PERSONAL STAFF}

The article analyzes personal staff of castle chancery of Novhorod-Siverskyi during its functioning (1636-1648). The origin of its officials and lower staff was established and their career was investigated within the chancery and in the nobility's society. It was proved that all permanent employees were clients of Oleksandr and Yan Pisochynskyis, who were captains. They received from patrons land estates on the rights of ownership or lease for the service in the chancery. The article describes staffing flows of lower employees from chanceries of Ukrainian palatinates of the Polish-Lithuanian Commonwealth to castle chancery of Novhorod-Siverskyi. Newly created in the middle 1630-s, a castle chancery of Novhorod-Siverskyi as a centre of the royal administrative and judicial power could not rely on fact of law and office administration schools existence in the region, so, staff for it was involved from other territories of Polish-Lithuanian Commonwealth. The court of O.Pisochynskyi, which has been formed mostly from ex-participants of military expeditions in ruled by him chapters, was the main supplier of staff for the chancery. Another part of employees consisted of well-experienced castle chancellors and councilmen of the Ukrainian voivodeships of Polish-Lithuanian Commonwealth - Volyn, Kyiv and Braclav ones. The professional skills of applicants, akin links and personal fidelity to the captain were the criteria for the acceptance to the chancery. The geographical origin of the officials and lower staff of the chancery was diverse enough. We can separate three regions of Polish-Lithuanian Commonwealth, because people of this origin were fulfilling the staff of the Novhorod-Siverskyi castle chancery: Great Lithuanian principality, the Crown where Masovian voivodeship grounds dominated, and Ukrainian voivodeships. The general portrait of one of the officials of the chancery relies on the next characteristics: a noble; poor, who, as a rule, did not have any land behind the borders of Novhorod-Siverskyi district; well prepared in a field of law and office administration; a denominationally diverse (Catholic, Orthodox, Protestant); economically and, of course, personally dependent from a patron. For the lower chancery staff this list was broadening to the non-compulsory noble origin, high career mobility, mixing of work in chancery with the legal practice, at first, the participation in court proceedings as representatives of sides. In the context of the general portrait, the Novhorod-Siverskyi castle chancery slightly differed from its analogues in the neighbor Ukrainian voivodeships.

Keywords: castle, chancery, personal staff, captain, Novhorod-Siverskyi).

У системі судочинства й адміністрування Речі Посполитої одними з найбільш ефективних установ були гроди. Останні засновувалися в ключових королівських замках - центрах повітів - територіально-адміністративних одиницях, з яких складалися воєводства. На території українських воєводств (Київського, Волинського, Брацлавського, Чернгівського) налічувалося 7 гродсько-судових і 2 гродсько-урядових установи. 3 семи гродсько-судових установ три (луцький, володимирський, кременецький) знаходилися у Волинському воєводстві, один (Брацлав/Вінниця) у Брацлавському, 
два (Чернігів, Новгород-Сіверський) у Чернігівському і один (Київ) у Київському. Дві гродсько-урядових установи розміщувалися у Київському воєводстві - Житомирі й Овручі.

Найпізніше гроди з'явилися у Чернігівському воєводстві. 3 формальної точки зору їх виникнення мало відбутися в два етапи. У Чернігові грод мав з'явитися як результат схвалення конституції коронаційним сеймом 1633 р. під назвою «Ординація чернігівська» [83, s. 210]. У цій конституції визначалася й правова основа функціонування цього гроду - «право і статут київські». Під цим терміном розумівся симбіоз Другого Литовського статуту 1566 р. й коронних конституцій, відомий у джерелах переважно як «Волинський статут» чи «волинське право». Під час того ж сейму (22 лютого) відбулася номінація Мартина Калиновського на уряд чернігівського гродського старости [39, л. 26 об. - 27]. Зважаючи на те, що до середини 1634 р. тривала Смоленська війна, фактичне повстання гроду у Чернігові відкладалося на майбутнє. Як наслідок, у Чернігові гродський суд щонайпізніше почав діяти у першій половині 1635 р. [69, k. 9; 47, с. 158, 171]. Другий етап цього процесу припав на час роботи коронного сейму 1635 р. (січень-березень). Цей сейм схвалив конституцію «Ординація воєводства Чернігівського» [83, s. 265]. У ній передбачено створення гроду в Новгороді-Сіверському. Новгород-сіверським старостою з 22 жовтня 1633 р. вже був Олександр Пісочинський [56, k. 235-235 v.]. 3 часу схвалення конституції він ставав гродським старостою. Зрозуміло, що для організації роботи гроду потрібний був певний час. Найбільш важлива складова цієї установи гродський суд зафіксований у відомих нам джерелах з лютого 1636 р. [25, арк. 177-177 зв.].

Таким чином, новгород-сіверська гродська канцелярія, правдоподібно, була сформована впродовж другої половини 1635 р. Оскільки вона формувалася одноосібно старостою, то зрозуміло, що до іiї складу увійшли люди Пісочинських - Олександра, київського каштеляна, й його сина Яна, старости 325 лютого 1641 р. [26, арк. 4-4 зв.]. Поступка староства на користь сина була складовим елементом проекту військової реформи, запропонованого київським каштеляном. На його думку, українські магнати мали отримати право вічної держави на всі маєтності, які входили до складу староств (як гродових, так і негродових). 3 кожної такої маєтності її державець мав виставляти певний загін озброєних людей до коронного війська. Більше того, Олександр практично створив таку систему в своїх новгород-сіверських володіннях. Число його приватного війська, яке мало ставати на «кожну послугу» свого патрона і складалося з державців, клієнтів, козаків, осаджених на землю 3 умовою виконання військової служби, сягало 3-х тисяч. Крім цього, київський каштелян утримував в тих само володіннях одну хоругву драгунів і ще одну - угорської піхоти загальною чисельністю 200-300 жовнірів [67, s. 64-65, 193-194]. Зважаючи на це, король Владислав IV, попри те, що реформа О. Пісочинського залишилася нереалізованою, дозволив як виняток поступитися йому новгородсіверським гродським староством на користь сина.

Всі урядники канцелярії разом зі старостою (якщо він був щойно призначений) складали присяги перед шляхтою, найбільш ймовірно під час проведення сеймику [51, арк. 3-6 зв.]. Старости доволі рідко брали особисту участь у засіданнях гродського суду [20, арк. 40-41, 47-48], а ще рідше були присутніми в канцелярії впродовж міжсесійних періодів. Достеменно відомо, що Олександр Пісочинський брав особисту участь у січневих рочках 1639 та 1641 p. [65, s. 761; 17, арк. 149-149 зв.], а Ян Пісочинський - у червневих рочках 1645 р. [20, арк. 40-41, 47-48]. Традиційно, особливо, коли йшлося про розгляд справ, де стороною виступав сам староста, його могли заміщувати субделегати. Субделегати призначалися одноосібно старостою і могли виконувати свої обов'язки голови суду як одноразово, так і протягом всього часу відбуття рочок [25, арк. 177-177зв.]. В часи старостування О. Пісочинського такі обов'язки покладалися на Адама Вишневського $(1636,1639)$, Щасного Вишля (1636), Каспера Ростопчу $(1637,1639)$, Ремігіана Горчинського (1638) [25, арк. 177-177 зв., 226-227 зв.; 15, арк. 27 зв., 99-100 зв.; 16, арк. 79-79 зв., 80-81, 97-97 зв., 99-99 зв.; 24, арк. 19]. Всі вони належали на час виконання повноважень субделегатів до верстви земських урядників: А. Вишневський - новгород-сіверський земський підсудок (1628-1637), земський суддя (1637-1642), Щ. Вишель - новгород-сіверський підкоморій (1635-1641), К. Ростопча - новгород-сіверський земський писар (1637-1647), Р. Горчинський - латичовський войський (1638-1650) [9, c. 404, 407, 411; 82, s. 185]. Всі вони були «осілими» (тобто мали земельні володіння) на території Новгород-Сіверського повіту [9, с. 422-431]. Перші троє, судячи з займаних урядів, мали поважну судову практику. Усіх чотирьох важко назвати людьми, залежними від О. Пісочинського. Відтак, О. Пісочинський при відборі кандидатур на субделегатство ретельно дотримувався чинного законодавства. Слід звернути увагу на хронологічні межі призначень старостою субделегатів. Вони завершуються 1639 р. і не ви- 
падково. 3 того часу фактичне керівництво рочками концентрується в руках судового підстарости. В часи старостування Яна Пісочинського субделегат «на місці старости» фіксується лише у червні 1646 і серпні 1647 рр. Ним є Ян Сковродка [20, арк. 61-63 зв.; 21, арк. 116-118 зв.; 24, арк. 74]. Він був особою нижчого рівня, ніж субделегати О. Пісочинського. Відомо лише, що у його володінні знаходився населений пункт Івантенки поблизу адміністративної межі Новгород-Сіверського повіту з Стародубським повітом Смоленського воєводства [33, л. 379-381]. Втім і авторитет сина Яна відверто не дотягував до рівня його батька - київського каштеляна, відомого дипломата й одного 3 примітних воєнних керівників часу Смоленської війни.

Судові підстарости головували на більшості судових засідань рочок. За досліджуваний період у канцелярії працювало чотири судових підстарости: Миколай Лютостанський (липень-листопад 1636), Криштоф Муховецький (грудень 1637 - листопад 1642), Станіслав Ореховський (червень 1643 - липень 1644), Вацлав Кринський (червень 1646 - січень 1648) [30, л. 41, 42, 241; 16, арк. 102-102 зв.; 17, арк. 48-48 зв., 51-51 зв.; 25, арк. 203; 18, арк. 135-136; 19, арк. 1-2, 108-108 зв.; 20, арк. 61-61 зв.; 26, арк. 152; 65, k. 761, 785, 814 v., 922 v., 934 v.].

Всі вони, без сумніву, були особами залежними від Пісочинських. М. Лютостанський, родове гніздо якого знаходилося в Ломжинській землі Мазовецького воєводства [76, s. 126], фіксується як рукодайний слуга О. Пісочинського ще з середини 1620 -х рр. У 1625 р. Богдан Копієвський звинувачував людей О. Пісочинського, в тому числі й М. Лютостанського, у нападі на його замочок Кунич у Брацлавському воєводстві. Довести це йому не вдалося і 1630 р. за рішенням Коронного трибуналу в Любліні він мав сплатити 200 гривен і 10 тисяч золотих О. Пісочинському. Останній поступився цією сумою (ще нестягненою з Миколая Копійовського, сина Богдана [74, s. 120]) на користь саме М. Лютостанського [13, арк. 117-117 зв.; 14, арк. 120-120 зв.]. Очевидно, що 3 прибуттям О. Пісочинського на Чернігово-Сіверщину туди ж перебрався і М. Лютостанський.

Родина Криштофа Муховецького гербу «Побог» походила з Цеханувської землі Мазовецького воєводства. Наприкінці XVI ст. іï представники з'являються на Київщині. Зокрема, королівський дворянин, а згодом становничий Юрій Муховецький отримав ряд спірних володінь у Київському воєводстві (Бернавку, Івницю) [37, л. 161 об. - 162; 38, л. 54-54 об., 90 об. - 91; 40, л. 18 об. - 21 об. ]. Наприкінці XVI ст. одним з писарів Коронної канцелярії був Станіслав Муховецький [80, s. 339]. Можна припустити, що обоє мали знайомство з батьком Олександра Лаврином, який свою кар'єру зробив якраз у королівській канцелярії. Невідомо в якій спорідненості перебував Криштоф до двох згаданих Муховецьких. Однак, можна припустити, що його доля звела 3 новгород-сіверським старостою під час Смоленської війни. Принаймні, перші роки перебування Криштофа на ЧерніговоСіверщині аж ніяк не свідчить про пряму залежність від старости. Більше того, перше володіння, яке отримав К. Муховецький в регіоні - Верхолісся - знаходилося у Чернігівському повіті. У 1636 p. він поступився ним (тобто продав) новгород-сіверському хорунжому Миколаєві Киселю [57, k. 61 v. - 62]. На той час, напевно, вже існувала домовленість між Криштофом і О. Пісочинським про обопільно вигідну співпрацю. Не випадково, що з цього часу К. Мухавецький почав активно набувати земельні володіння саме у Новгород-Сіверському повіті. У 1636 р. він купив у стародубського земського судді Яна Кунинського населені пункти Чаусів, Вітельм, Дешковичі, Городище, у 1637 p. - Пушкарі. 1636 р. К. Муховецький набув в Адама Ізбицького село Камінь [57, k. 60 v. - 61, 169 v. $-170,173$ v. -174$]$. Це створило необхідну умову для зайняття відповідного уряду в гродській канцелярії. На коронному сеймі 1640 р. Криштоф був призначений поборцею Чернігівського воєводства [83, s. 358]. За чотири роки К. Муховецькому вдалося зібрати трохи більше $81 \%$ визначеного для воєводства подимного податку, що відповідало тогочасним податковим практикам [9, с. 183-184]. Причини відходу/усунення Криштофа з уряду судового підстарости залишаються невідомими. Козацька революція позбавила його новгород-сіверських володінь. Збідніння родини призвело до пошуків «хліба» незаконними шляхами. У 1655 р. він разом з синами Владиславом і Костянтином за розбійництво і грабежі на «публічних дорогах» були засуджені на інфамію. Однак, коронний сейм 1658 р., зважаючи на їх заслуги у коронному війську, зняв з них цю інфамію [84, s. 419; 80, s. 339].

Наступний підстароста Станіслав Ореховський фіксується в оточенні О. Пісочинського 3 кінця 1634 - початку 1635 р., коли новгород-сіверський староста разом з Казимиром Левом Сапєгою очолював посольство до Москви. Тоді Станіслав був визначений одним з суддів, які мали стежити за порядком і вирішувати можливі конфлікти серед членів посольства [77, s. 30]. Судячи із зображення на печатці, Станіслав належав до родини Ореховських гербу «Любич». Родина мешкала в XVII ст. 
у Вількомирському і Браславському повітах Віленського воєводства [78, s. 243, 246, 273]. Схоже на те, що він обирався повітовим ротмістром і був протестантом [66, s. 206]. 3 середини 1637 р. він фіксується як новгород-сіверський гродський суддя. На цьому уряді Станіслав залишався, принаймні, до березня 1643 р. [15, арк. 99-100 зв.; 16, арк. 80-81, 102-102 зв.; 17, арк. 51-51 зв.; 18, арк. 112-112 зв.; 65, k. 761, 785, 814 v., 818 v., 922 v., 934 v.]. Час від часу виступав довіреною особою старости, як у липні 1639 р., коли входив до складу комісії щодо полагодження суперечки між О. Пісочинським і К. Ростопчею та встановлення меж між староством і селами К. Ростопчі [58, k. 222 v. - 224 v.]. Урядники гродської канцелярії, як відомо, обов'язково повинні були бути «осілими» у своєму повіті. Такі маєтності С. Ореховський отримав, правдоподібно, за поступкою О. Пісочинського. У середині 1640-х рр. Станіслав володів населеними пунктами Землянка у Глухівській волості та Княжа у східній частині Новгород-Сіверського повіту [18, арк. 113-117 зв.]. Помер Станіслав до козацької революції 1648 р. Був якимсь родичем Криштофу Силичу (правдоподібно, братом його дружини) i, як наслідок, згадані маєтності після смерті Станіслава дісталися саме Силичам [6, арк. 28].

Вацлав Кринський належав до родини гербу «Пржегіня», осілої в Дрогицькій землі Троцького, а 31513 р. Підляського воєводства [75, s. 379]. Кар'єру в канцеляріях розпочав як підписок луцької гродської канцелярії в 1627 р., продовжив знову ж таки як підписок, але у володимирській гродській канцелярії (1627-1629) [53, с. 334, 351]. 31631 по 1636 р. Вацлав виконував функції бурграбія у Кременці $[49$, арк. 53; 50, арк. 2, 6]. У новгород-сіверському гроді В. Кринський з'явився у середині 1640-х рр. і прослужив до козацької революції. Подальша його доля невідома.

Так само, як у випадку зі старостами, при розгляді судом справ, в яких стороною виступали підстарости, їх замінювали субделегати. У 1639 р. субделегатом замість підстарости К. Муховецького був вже згадуваний латичовський войський Ремігіан Горчинський. У тому ж році того ж підстаросту заміщував ще один субделегат - Силуян Мужиловський, який певний час займав уряд гродського писаря $[65$, k. $765,771,776$ v., 818 v.].

Частіше ж, у період роботи канцелярії між рочками, підстарост замінювали намісники. За досліджуваний період їх налічувалося, щонайменше, вісім. Їх обов'язки не мали чітко визначеного часового виміру. Логічно було б думати, що їх на певний відрізок часу призначав староста або 3 працівників канцелярії, або ж довірених осіб, що виконували інші доручення старости.

Ян Нарбут фіксується як намісник судового підстарости впродовж грудня 1636 - липня 1637 pp.[15, арк. 76-76 зв., 85, 132-132 зв.; 16, арк. 4; 24, арк. 17]. Він походив, швидше всього, з литовської родини гербу «Труби» [81, s. 27]. Напевно, належав до табору слуг і клієнтів О. Пісочинського. Зважаючи на його литовське походження, можна здогадно думати, що в сфері впливу новгород-сіверського старости опинився під час Смоленської війни.

Самуель Дідковський, один з найбільш різнопланових працівників канцелярії, періодично згадується як намісник судового підстарости з вересня 1639 до березня 1647 р. [16, арк. 123-124; 17, арк. 54, 61, 86-87; 19, арк. 136-136 зв., 177; 24, арк. 21, 22, 23, 24, 68, 71, 73; 52, арк. 407 зв.]. Він походив 3 овруцької шляхетської родини Дідковських гербу «Сас» [71, s. 129]. Згідно даних подимного реєстру Овруцького повіту 1634 р. Дідковські у селі Дідківці володіли всього трьома родинами підданих [48, арк. 924 зв.]. Достеменно невідомо, стільки сімей Дідковських проживало на той час у Дідківцях, але згідно неповних даних середини XVII ст. - не менше чотирьох [1, с. 142-146]. Для такої дрібної шляхти шлях до достатку лежав поза межами родинного гнізда і міг бути трояким: військова служба, духовна кар'єра й юриспруденція. Дідковські випробовували всі три шляхи [28, с. 39, 192; 10, с. 222; $54,259]$. Чимало представників родини потрапили на нижчі уряди в гродських і земських канцеляріях, зокрема у 1617 р. якийсь Дідковський зафіксований як земський підписок у Києві; у 1643 р. у житомирській гродській канцелярії фігурує Захаріяш Петрович Дідковський, а під 1648 р. згадується знову ж таки як київський земський підписок Дідковський [53, с. 340, 342; 54, с. 258]. Самуель вперше фіксується як підписок у Новгороді-Сіверському у травні 1637 р. і виконував ці функції до жовтня 1645 р. [15, арк. 86 зв.; 20, арк. 89-89 зв.]. У грудні 1640 - березні 1641 р. він періодично згадується як гродський писар [17, арк. 48-48 зв., 125-126 зв., 128, 156-157]. Поза всіляким сумнівом, це було тимчасове виконання цих функцій, пов'язане з якоюсь обгрунтованою відсутністю в Новгороді-Сіверському «основного» писаря Самуеля Некрашевича. У лютому 1641 р. С. Мужиловський, що тоді виконував функції гродського писаря, перед від'їздом на Коронний трибунал у справах О. Пісочинського «засадив» на своє місце субделегатом саме С. Дідковського [17, арк. 156-157]. 31644 р. Самуель згадується як чернігівський граничний коморник [19, арк. 136-136 зв., 177; 20, 
арк. 54-54 зв.; 24, арк. 71, 73]. Час від часу він, як вже зазначалося, здійснював повноваження намісника, поєднуючи їх з обов'язками підписка. Крім цього, Самуель надавав юридичні послуги клієнтам з числа місцевої шляхти як їх уповноважений у різних судах [65, s. 806 v., 892 v., 913 913 v.]. Проживав у селі Медведків (Медведки), в окрузі Новгорода-Сіверського [18, арк. 113-117 зв.]. Правдоподібно, Самуель орендував його в Пісочинських. У серпні 1646 р. Самуель перебував у Сосниці, названий слугою Яна Пісочинського і знову «писарем гродським новгород-сіверським» [22, арк. 34-35].

Ще одним вихідцем з овруцької шляхти у канцелярії був Ян Закусило [54, с. 251]. За подимним реєстром 1634 р. Закусили володіли трьома димами у селі Закусили [48, арк. 926 зв.]. Варіанти вибратися «в світ» у них були аналогічними, що й у Дідковських. Зокрема, у 1643-1646 рр. спочатку у житомирській гродській, а згодом - в овруцькій замковій працював як підписок Іван Закусило [53, c. 337, 355]. Новгород-сіверський Ян (напевно, інша особа, ніж Іван) з'явився у місцевій канцелярії як підписок не пізніше осені 1636 р. [24, арк. 12]. Ці функції він виконував до середини 1645 р. [20, арк. 40-41]. Пік його кар'єри в канцелярії припав на 1646 р., коли Ян згадується як регент (старший підписок) [22, арк. 79]. Протягом цих 11 років Я. Закусило неодноразово виступав як намісник судового старости, зокрема у грудні 1640 - березні 1641 р. [17, арк. 115, 152-152 зв.; 18, арк. 91-93; 24, арк. 29]. При цьому, так само як і С. Дідковський, він поєднував ці функції з обов'язками підписка. Видається, що саме цей Ян Закусило у грудні 1653 р., маючи при собі як уповноважений справи Луцького і Корецького монастирів, був у дорозі під Паршовою або вбитий татарами, або захоплений в полон [28, с, 310].

Станіслав Буринський (Буржинський) представляв, ймовірно, шляхетську родину гербу «Тривдар», осілу з початку XVI ст. на Поділлі [2, с. 344-345]. На початку XVII ст. Буринські тримали село Марківці Кам'янецького староства [70, s, 258]. Станіслава з О. Пісочинським доля могла звести як внаслідок контактів на Поділлі (з початку 1630-х рр. Олександр посідав уряди кам'янецького каштеляна й уланівського старости), так і під час ймовірної служби Буринського у короному війську - О. Пісочинський був королівським ротмістром і одним організаторів антитатарської оборони на Поділлі. Як намісник судового підстарости Станіслав зафіксований у джерелах з грудня 1637 до січня 1643 р. [15, арк. 132-132 зв.; 41, л. 13]. Крім цього, він засвідчував виписи 3 новгород-сіверських гродських книг за відсутності писаря [17, арк. 61; 18, арк. 83].

Короткий період (згадка датується березнем 1641 р.) обов'язки намісника судового підстарости Мартин Ягодинський [17, арк. 156-157; 24, арк. 35]. Він походив 3 шляхетської родини гербу «Корвін», осілої у Холмській землі Руського воєводства [72, s. 149]. Зважаючи на те, що його урядування припадає на початок старостування Яна Пісочинського і може означати спробу останнього продемонструвати незалежність від свого батька, який фактично подарував йому уряд старости. Навряд, чи така демонстрація була успішною з огляду швидке «відсторонення/зникнення» М. Ягодинського від роботи у новгород-сіверській гродській канцелярії.

Більш відомою особою в повіті був ще один намісник судового старости (червень 1642 р.) Криштоф Силич. Він походив 3 шляхетської родини Берестейського воєводства. Там його предки у середині XVI ст. володіли селом Забаб’є [6, арк. 28], однак в останній третині того ж століття його власниками виступають Радзівіли. К. Силич, давній клієнт О. Пісочинського, отримав наприкінці 1630-х рр. від патрона право на осадження слобідки Бобрик і всієї Погарської волості, поблизу адміністративної межі Новгород-Сіверського повіту з Стародубським повітом [9, с. 237, 300, 301, 303]. Маючи підтримку Олександра К. Силич дозволяв собі «наступати» на маєтності (Лобки) новгородсіверського войського Якуба Міляновського [17, арк. 48-48 зв., 81-82; 18, арк. 60-62, 95-96.]. Оцінюючи заслуги свого осадчого київський каштелян у 1642 р. поступився йому своїм правом на слобідку Новий Бобрик [9, с, 444]. Як вже відзначалося, по смерті С. Ореховського К. Силичу дісталися маєтності Землянка і Княжа; по небіжчику Андрію Липені - Щерби. Крім цього, Криштоф купив ще цілий ряд маєтностей у Новгород-Сіверському повіті (принаймні, він про це заявляв у лютому 1650 р.): Некрасове і Павловське у Мацея Жуковича, Сліпород і Лазарки у Войцеха Івицького, Ястрембщину або ж Мерву в Себастіана Ястрембського. Також за привілеєм Сигізмунда III батько Криштофа Григорій мав у пожиттєвому володінні Копивницю у Любецькому старостві, під Лойовим [6, арк. 28]. Цей привілей, нібито, мав бути потверджений Владиславом IV для Криштофа, однак люстрація Любецького староства 1636 р. фіксує цей населений пункт у посесії Адама Калиновського [85, s. 127, 209]. Поширення козацького повстання на Чернігово-Сіверщину мало катастрофіч- 
ні наслідки для сім’і Криштофа. Він втратив не лише земельні володіння і привілеї на них, але й дружину та дітей. Якийсь час і він сам вважався загиблим, бо наприкінці грудня 1649 р. Бобрик за королівським привілеєм, нібито по смерті Силича, був наданий королівському ротмістрові Анджеєві Курпському [62, k. 259 -259 v.; 64, k.. 211-211 v.]. Однак, ще в лютому 1650 р. Криштоф вніс маніфестацію про втрачені маєтки і привілеї до володимирського гроду. Якісь добра К. Силич, нібито, мав надати Батуринському дівочому монастирю [46, с. 149].

Ян Мелешко Пишинський, що згадується як намісник судового підстарости у вересні 1643 р. [18, арк. 157-158], належав до розгалуженого литовського роду Мелешків гербу «Корчак». Найраніше Мелешки зафіксовані у Смоленській землі, а після їі захоплення московськими військами переселилися в інші литовські й українські землі, зокрема на Волинь, Поділля й Брацлавщину. Пишинські складали одну з гілок роду Мелешків. Зокрема, Юрій Мелешко Пишинський служив князеві Острозькому, правдоподібно Василеві-Костянтинові [79, s. 396-397]. Яким чином і коли Ян опинився в оточенні новгород-сіверських старост, відповісти поки неможливо.

Більш знаною особою є Томаш Малаховський, намісник судового підстарости в серпні-вересні 1647 р. [23, арк. 145-145 зв., 173-173 зв.; 24, арк. 72]. Томаш був заслуженим жовніром, учасником багатьох експедицій. Під час облоги Новгорода-Сіверського потрапив до московського ув'язнення. Під час допиту повідомив, що походив з Київського повіту, де мав маєтність. Близько 1629 р. отримав якесь помістя у Новгород-Сіверському повіті. У Новгороді-Сіверському служив підписком, правдоподібно у земському суді обох повітів (Новгород-Сіверського і Чернігівського) при писарю Янові Струпчевському [36, л. 160-165]. Після повернення з полону, у серпні 1634 р. він отримав ленним правом четверту частину слободи і трьох підданих у Стародубському повіті Смоленського воєводства [36а, л. 492 об. - 493]. У 1636-1638 pр. Томаш брав участь в підготовці та забезпеченні проведення розмежування між Річчю Посполитою та Московською державою [31, л. 66; 32, л. 393]. Десь на переломі 1630-1640-х рр. Т. Малаховський мав посісти уряд стародубського городничого. Попри це, часто бував а може й мешкав у Новгороді-Сверському, бо на початку лютого 1643 р. саме тут на міському ринку возний вручив йому позов від Кристини Стравінської [18, арк. 113-117 зв.]. У першій половині 1646 р. Томаш виконував обов'язки старости в Сосниці, володінні на той час Ельжбети з Остророга Пісочинської, хоча зведений був на посаду ще покійним О. Пісочинським [68, k. 29]. Там староста вступив у змову з пасинком Ельжбети Яном і допоміг йому оволодіти Сосницею і замком в середині того ж року. За це Ян винагородив його урядом новгород-сіверського провентового (господарського) старости [8]. На Томаша старостою були покладені обов'язки, в тому числі й врегулювання суперечок з прирубіжними московськими воєводами [34, л. 8-11, 29-29 об., 32-32 об.; 35]. Ці функції він виконував аж до початку козацької революції [35, л. 267-268, 355-356].

Уряд гродського судді займали з 1636 р. дві особи - С. Ореховський (листопад 1636 - лютий 1643) [24, арк. 11-12; 15, арк. 99-100 зв.; 18, арк. 157-158] та Мартин Київський (червень 1643 - червень 1647) [18, арк. 135-136; 26, арк. 142 зв.]. Про С. Ореховського як підстаросту йшлося вище. М. Київський гербу «Юноша» мав належати до роду, що походив з Руського воєводства [73, s. 72-73]. 3 молодих років брав участь як жовнір у різних військових експедиціях: прусській 1626-1628, московській 1632-1634, декількох козацьких, напевно 1630 і 1637-1638 рр. у роті вінницького старости Яна Одживольського. На вальному сеймі 1639 р. за свої заслуги Мартин отримав привілей на ряд ленних володінь у Чернігівському воєводстві по смерті Яна Сіножацького, зокрема пустош Вербщизну у Новгород-Сіверському повіті, с. Козленичі, «острови» Убідський і Шадринський у Чернігівському [58, k. 169 v. - 170]. Вдова Я. Сіножацького Теофілія Розсудовська, яка мала спільне з Я. Сіножацьким пожиттєве право на ці ленні володіння, оригінально знайшла вихід з казусної ситуації і вийшла заміж за М. Київського. Це призвело до тривалої суперечки між подружжям і братом померлого Яна - Криштофом Сіножацьким. Процес, зрештою, завершився на користь подружжя. Більше того, у 1644 р. Т. Розсудовська поступилася своїм правом М. Київському [9, с, 85]. У червні 1645 р. цю поступку і привілей М. Київському потвердив король Владислав IV [61, k. 229-231]. Певні права на Вербщизну мав і О. Пісочинський, але він також поступився ними на користь М. Київського [9, c. 297]. Так само вдалося гродському судді відстояти свої права на Козленичі, які оспорював в асесорському суді на початку 1647 р. Адам Кисіль [63, k. 306-311 v.]. Сліди М. Київського загубилися у вирі Національно-визвольної війни, але, без сумніву, він їі не пережив, бо його володіння опинилися в інших руках, як формально - $з$ точки зору Варшави, так і фактично - у межах козацької держави. 
У випадку гродської канцелярії у Новгороді-Сіверському не вдалося виявити випадків делегування повноважень судді третім особам. Слід припустити, що у ситуації, коли справа стосувалася судді, він просто не брав участі у процесі; його обов'язки, як видається, виконував судовий підстароста.

Протягом всього часу функціонування новгород-сіверської гродської канцелярії у ній працювало три писарі.

Від самого початку формування канцелярії і до його припинення гродським писарем згадується Самуїл Некрашевич [15, арк. 76-76 зв.; 23, арк. 173-173 зв.]. Він походив 3 шляхетського роду гербу «Любич», осілого на теренах Великого князівства Литовського [81, s. 89]. Судячи з джерельних даних Самуїл прожив тривале (понад 90 років) і багате на події життя. Кар'єру свою він розпочав як юрист родини Пісочинських, насамперед Олександра. Надання юридичних послуг цій родині зафіксоване впродовж 1617-1622 рр. Тоді Самуїл писався «з Рожина (Ружина)», що, ймовірно, вказувало на його тодішнє місце проживання - в Київському воєводстві [11, арк. 141-142 зв.; 12, арк. 13-14, 129-130, 133-133 зв.]. А в 1622 р. він згадується як шляхтич (тобто слуга) Олександра і Якуба Пісочинських [21, арк. 80-80 зв.]. Сповідував православ'я [19, с. 223]. Згодом, число клієнтів С. Некрашевича розширилося - у 1633 р. у Коронному трибуналі в Любліні він представляв інтереси руської воєводини Софії Данилович [42, с. 248]. Після завершення Смоленської війни Самуїл подався вслід за патроном (О. Пісочинським) на Чернігово-Сіверщину, де й обійняв уряд гродського писаря. Згідно подимного реєстру Київського воєводства 1640 р. Самуїл сплатив податок з маєтностей Лебединці і Шумилівці, в яких нараховувалося 16 димів [48, арк. 880]. Чи був він лише їх орендарем, чи власником, відомі нам джерела замовчують. Натомість, достеменно відомо, що С. Некрашевич отримав ленним правом у серпні 1643 р. пустош Рахмани над р. Буйна та Дворище, з іншого боку тієї ж річки [60, k. 34-34 v.]. Обидві маєтності фактично знаходилися у Стародубському повіті Смоленського воєводства. Згодом, Рахмани Самуїл поступив (продав/виміняв) О. Пісочинському [9, с. 303,444$]$. Після цього їх стали відносити до Погарської волості Пісочинських і Новгород-Сіверського повіту. Швидше всього, мотивацією до поступки Рахманами став факт надання в оренду О. Пісочинським Самуїлу села Кириївщина у Сосницькій волості [18, арк. 113-1173в.]. У 1638-1639 pp. С. Некрашевич згадується як державця фільварку неподалік Костерова [65, k. 853]. Ці землі належали О. Пісочинському як старості. Козацька революція перервала доволі успішну кар'єру Самуїла. Де

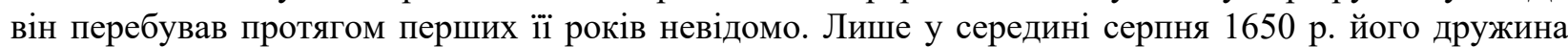
Маруша маніфестувала перед житомирським гродським урядом про втрату 1648 р. під час козацької війни документів на маєтки у Київському, Чернігівському і Смоленському воєводствах [28, с. 179]. Самуїл на довгі роки, якщо не десятиліття, випав з активного політичного чи соціально-економічного життя. Можливо перебував у полоні. У джерелах С. Некрашевич «виринає» лише наприкінці 1680-х pp. У 1688 р. подружжя Некрашевичів (Самуїл і Маруша) купили у Тимофія і Маруші Коркошків Губарівський грунт у селах Мочульниця і Піщаниця Овруцького повіту. Тоді ж подружжя тримало в заставі від Андрія Черхавського іншу частину Піщаниці. Син Некрашевичів Стефан мав якісь заслуги перед Річчю Посполитою, за що отримав подяку від короля [29, с. 6]. Автори гербовника «Rodzina» вказали, що дружиною Самуїла була Кристина Суходольська, а Стефан отримав уряд чернігівського войського $[81,89]$. Підтверджень цій інформації виявити не вдалося.

3 незрозумілих для нас причин наприкінці 1640 - першій половині 1641 р. С. Некрашевич усунувся/був усунутий від виконання фактичних обов'язків гродського писаря. Напевно, у зв'язку з певними обставинами С. Некрашевич не міг регулярно виконувати свої писарські функції, тому писарем також був призначений Самуель Мужиловський (згадується як писар періодично від грудня 1640 по вересень 1642 р. [17, арк. 115; 18, арк. 70-70 зв.]), а Самуель Дідковський заміщував останнього (серпень 1640 - березень 1641 р.) [24, арк. 26; 17, арк. 125-126 зв., 128, 156-157] - одного разу він згадується як “засаджений субделегатом на місці своєму писарському від С. Мужиловського” [17, арк. 156-157]. Згодом С.Дідковський знову повернувся до виконання у канцелярії обов'язків підписка (про нього йшлося вище).

Самуель або Силуян Мужиловський [45, с. 402] походив з шляхетської родини, осілої у Великому князівстві Литовському. Його батьком був відомий полеміст, слуцький протопіп, а згодом ієромонах Києво-Печерського монастиря Андрій Мужиловський. У шлюбі з Анастасією Чижівною Андрій мав, щонайменше, двох синів: Михайла і Самуеля (Силуяна) [80, s. 321]. На початку 1630-х pp. Самуель навчався в лаврській Могилянській школі, де під керівництвом вчителя риторики Софронія Почаського взяв участь в укладенні «Євхаристіону або вдячності Петрові Могилі», написавши до неї 
вірш про діалектику [44, с. 244]. Невдовзі по завершенні навчання Самуель опиняється в НовгородіСіверському, де став у 1636 р. писарем гродської канцелярії [24, арк. 11-12]. Але брак досвіду (діловодного і юридичного) не дозволив йому утриматися на уряді; незабаром староста надав перевагу більш досвідченому С. Некрашевичу. Втім, у березні 1639 р. Силуян (так у вписі) зафіксований як «засаджений» на місце новгород-сіверського гродського писаря [65, k. 853]. Згодом, наприкінці 1640 - середині 1642 рр. Самуель (Силуян) повертає собі місце писаря у гродській канцелярії. Час від часу він надавав юридичні послуги старості О. Пісочинському [19, арк. 6-7; 24, арк. 35]. Тоді ж Самуель (Силуян) мав в оренді село Садки [18, арк. 116] в Радогощській волості київського Пустинного Микільського монастиря в Овруцькому повіті. 3 початком козацької революції Силуян, без сумніву, людина православна, опинився в таборі Богдана Хмельницького. Там зробив швидку й блискучу кар'єру: козацький полковник, військовий писар, суддя, дипломат [27], - ось неповний перелік урядів, які він займав. Колишній працівник новгород-сіверської гродської канцелярії загинув під час одного з конфліктів між козаками в проміжку між 1654 і 1657 pp.

У березні 1639 р. як субделегат на місці писаря С. Некрашевича фігурує Самуель Ссмонт (Ейсмонт, Гісмонт) $[65$, k. 914 v.]. Він походив з роду Ссмонтів гербу «Кораб», осілого у Гродненському повіті Троцького воєводства Великого князівства Литовського [71, s. 238-239]. У 1619 р. джерела фіксують Самуеля у Луцькому повіті [3, с. 160]. На Волині Єсмонти 3'являються ще раніше - принаймні, з кінця XVI ст. [43, с. 103]. Власне, сам Самуель вже в 1630-х рр. одружився з представницею волинського шляхетського роду Козинських - Анною. С. Ссмонт як товариш хоругви литовського підстолія Криштофа Сапєги взяв участь у московській (1616-1618) та волоській (Хотинська битва, 1621) експедиціях. За військові заслуги у березні 1624 р. Самуель отримав ленним правом населений пункт Савинки у Новгород-сіверському повіті [55, k. 478-479]. Цінність цієї маєтності полягала в наявності поблизу перевозу через Десну. У Новгороді-Сіверському він увійшов до команди місцевого капітана Щасного Вишля, що здійснювала військово-адміністративне управління замком і повітом [9, с. 57]. Поза всіляким сумнівом, С. Ссмонт взяв участь у Смоленській війні. У грудні 1642 р. Самуель разом 3 дружиною мали намір здійснити обмін ленними маєтностями у Новгород-Сіверському повіті з місцевим земським писарем Каспером Ростопчею. Останній отримував Савинки, передаючи Єсмонтам населений пункт Клин [59, k. 224 v. - 226]. До того часу Самуель вже встиг поблизу Савинків заснувати слободу Туханів [9, с. 307]. 3 невідомих причин обмін не відбувся; у лютому 1643 р. подружжя Ссмонтів все ще мешкали у Савинках [18, арк. 113-117 зв.]. Як продовження цієї історії, у березні 1645 р. король Владислав IV дозволив Ссмонтам вчергове поступитися Савинками, Тухановим, перевозом через Десну та іншими належностями все тому ж К. Ростопчі [61, k. 247-248]. Продаж відбувся у травні 1646 р. [5, арк. 86 зв.]. На початку козацької революції С. Ссмонт з родиною (дружина і вісім дітей) потрапив до козацького полону. Лише в січні 1649 p. їх разом з групою іншої шляхти було звільнено загоном Станіслава Оршанського під Стародубом [4, с. 184].

Нижчий персонал новгород-сіверської гродської канцелярії воєводства представлений регентами та підписками. Як регенти у канцелярії виступають Ян Закусило (кінець 1646 - початок 1647 рр.) та Шимон Суронтовський (кінець 1647 р.). У цій само канцелярії як підписки працювали С. Дідковський, Я. Закусило, Ш. Суронтовський, Самуель Пантелеєвич, Дзвонковський.

Шимон Суронтовський у 1622-1646 pр. працював спочатку як підписок, потім як старший підписок вінницької гродської канцелярії. Часами залучався до аналогічної роботи у земській канцелярії Брацлавського воєводства [7, с. 91; 53, с. 328]. Судячи з імені, він був вихідцем з Корони. Здається, що його приналежність до шляхетської корпорації є сумнівною. Впродовж 1644-1645рр. Шимон представляв інтереси Анни з Красносельських, дружини покійного Якуба Пісочинського, у судових справах з їі дітьми [7, 91-92]. Відтак, у родині Пісочинських (діти Якуба були двоюрідними для Яна Пісочинського) юридична й діловодна кваліфікація Ш. Суронтовського були відомими, що могло сприяти переходу Шимона до новгород-сіверської гродської канцелярії, очолюваної на той час Я. Пісочинським.

Самуель Пантелеєвич, хоч і декларував себе шляхетним, ймовірно, вийшов 3 міщанського середовища. Зокрема, відомий у 1630-1642 рр. любецький війт Ярош Пантелеєвич [68, k. 25].

Дзвонковський (невідомий за іменем), швидше всього, походив з родини загродової шляхти гербу «Пшегоня», осілої у Ломжицькій землі Мазовецького воєводства [71, s. 220]. Його поява у Новгороді-Сіверському не $\epsilon$ чимось надзвичайним, зважаючи на достатньо інтенсивну динаміку напливу мазовецької шляхти на Чернігово-Сіверщину в 30-40-х рp. XVII ст. 
Отже, персональний склад новгород-сіверської гродської канцелярії формувався одноосібно старостами - спочатку Олександром, згодом Яном Пісочинськими. Новостворений у середині 1630-х рр. осередок королівської адміністративно-судової влади не міг опертися на факт існування в регіоні юридичних і діловодних шкіл, тому кадри для нього вербувалися з інших територій Речі Посполитої. Основним постачальником кадрів для канцелярії став двір О. Пісочинського, сформований його патроном переважно з колишніх учасників військових експедицій у складі керованих ним же підрозділів. Іншу частину працівників канцелярії склали досвідченні канцеляристи з гродських і земських канцелярій українських воєводств Речі Посполитої - Волинського, Київського і Брацлавського. Критеріями для прийняття в канцелярію виступали професійні якості претендентів, споріднені зв'язки та особиста відданість старості. Географічне походження урядників і нижчого персоналу канцелярії було достатньо різноманітним. Можна виділити три регіони Речі Посполитої, вихідці з яких наповнювали штат новгород-сіверської гродської канцелярії: Велике князівство Литовське, Корона, де домінували землі Мазовецького воєводства, і українські воєводства. Загальний портрет урядника канцелярії опирається на наступні характеристики: шляхтич; малозаможний, який, як правило, не мав земельних володінь поза межами Новгород-Сіверського повіту; добре підготовлений у праві й діловодстві; різноконфесійний (католик, православний, протестант); економічно, а, як наслідок, і особисто, залежний від патрона. Для нижчого канцелярського персоналу цей перелік розширювався на необов'язково шляхетське походження, вищу кар'єрну мобільність, поєднання роботи в канцелярії з юридичною практикою, насамперед участю в судових процесах в якості представників сторін. У контексті загального портрету новгород-сіверська гродська канцелярія мало чим відрізнялася від своїх аналогів у сусідніх українських воєводствах.

\section{Список використаних джерел та літератури:}

1. Архив ЮЗР (Архив Юго-Западной России, издаваемый Временной комиссией для разбора древних актов, учрежденной при Киевском, Подольском и Волынском генерал-губернаторе). Киев, 1867. Ч. 4: Акты о происхождении шляхетских родов в Юго-Западной России. T. 1. LV+461 с.

2. Архив ЮЗР. Киев, 1894. Ч. 8. Т. ІІ: Материалы для истории местного управления в связи с историей сословной организации. Акты Барского староства XVII-XVIII в. 274+497 с.

3. Ворончук I. Населення Волині в XVI - першій половині XVII ст.: родина, домогосподарство, демографічні чинники. Київ, 2012. 712 с.

4. Джерела з історії Національно-визвольної війни українського народу 1648-1658 pр. Київ, 2012. Т. 1: $1648-1649$ pp. $680 \mathrm{c}$.

5. Інститут Рукопису НБУ (Інститут Рукопису Національної бібліотеки України ім. В.І.Вернадського). Ф. I «Літературні матеріали». Спр. 4104. 420 арк.

6. Інститут Рукопису НБУ. Ф. 81 «Левицький О.І». Спр. 28.58 с.

7. Крикун М. Брацлавське воєводство у XVI-XVIII століттях. Статті і матеріали. Львів, 2008. 412 с.

8. Кулаковський П. Боротьба за спадщину: конфлікт між Яном та Ельжбетою Пісочинськими щодо новгород-сіверських маєтностей. Соиіум. Альманах соиіальної історії. Київ, 2005. Вип. 5. С. 127-139.

9. Кулаковський П. Чернігово-Сіверщина у складі Речі Посполитої (1618-1648). Київ, 2006. 496 с.

10. Літвін Г. Шляхта Київщини, Волині та Брацлавщини (1569-1648). Київ, 2016. 616 с.

11. ЛННБ (Львівська національна наукова бібліотека ім. В. Стефаника). Ф. 5 «Оссолінські». Спр. 4055. 155 арк.

12. ЛННБ. Ф. 5. Спр. 4056. 188 арк.

13. ЛННБ. Ф. 5. Спр. 4058. 154 арк.

14. ЛННБ. Ф. 5. Спр. 4059. 164 арк.

15. ЛННБ. Ф. 5. Спр. 4061.142 арк.

16. ЛННБ. Ф. 5. Спр. 4062.140 арк.

17. ЛННБ. Ф. 5. Спр. 4063. 223 арк.

18. ЛННБ. Ф. 5. Спр. 4064. 169 арк.

19. ЛННБ. Ф. 5. Спр. 4065.188 арк.

20. ЛННБ. Ф. 5. Спр. 4066. 140 арк.

21. ЛННБ. Ф. 5. Спр. 4067. 130 арк.

22. ЛННБ. Ф. 5. Спр. 4068. 165 арк.

23. ЛННБ. Ф. 5. Спр. 4069. 183 арк.

24. ЛННБ. Ф. 5. Спр. 4118. 126 арк.

25. ЛННБ. Ф. 5. Спр. 4138. 254 арк.

26. ЛННБ. Ф. 5. Спр. 4139. 225 арк.

27. Мицик Ю. Мужиловський Силуян. Полководияі Війська Запорозького: Історичні портрети. Київ, 1998. Вип. 1. С. 221-226.

28. Національно-визвольна війна в Україні 1648-1657. Збірник за документами актових книг. Київ, 2008. $1012 \mathrm{c}$. 
29. Опись актовой книги Киевского Центрального архива № 5. Киев, 1869. Книга гродская записовая, поточная и декретовая 1691, 94 и 95 гг. 62 с.

30. РГАДА (Российский государственный архив древних актов, г. Москва). Ф. 79 «Сношения России с Польшей». 1636. № 1а. 286 л.

31. РГАДА. Ф. 79. 1636. № 6. 272 л.

32. РГАДА. Ф. 79. 1638. № 9. 475 л.

33. РГАДА. Ф. 79. 1644. № 1.603 л.

34. РГАДА. Ф. 79. 1647. № 1.125 л.

35. РГАДА. Ф. 79. 1648. № 1.377 л.

36. РГАДА. Ф. 210 «Разрядный приказ». Новгородский стол. Стлб.27. 431 л.

36а. РГАДА. Ф. 389 «Литовская метрика». Оп. 1. Д. 110. 667 л.

37. РГАДА. Ф. 389. Оп. 1. Д. 200. 167 л.

38. РГАДА. Ф. 389. Оп. 1. Д. 201. 175 л.

39. РГАДА. Ф. 389. Оп. 1. Д. 214. 459 л.

40. РГАДА. Ф. 389. Оп. 1. Д. 218. 86 л.

41. РГАДА. Ф. 1473 «Поместно-вотчинные архивы юго-западных земель». Оп. 1. Д. 927.39 л.

42. Селянський рух на Україні 1569-1647 pр. Збірник документів і матеріалів. Київ, 1993. 535 с.

43. Собчук В. Шляхетський рід Лідихівських у XV - середині XVII століть. Крізь столітmя. Студї̈ на пошану Миколи Крикуна з нагоди 80-річчя. Львів, 2012. С. 92-126.

44. Українська література XVII ст.: Синкретична писемність. Поезія. Драматургія. Белетристика. Київ, 1987. $608 \mathrm{c}$.

45. Українські гуманісти епохи Відродження. Антологія. Київ, 1995. Ч. 2. 432 с.

46. Універсали Івана Мазепи 1687-1709. Київ; Львів, 2002. 757 с.

47. Филарет. Историко-статистическое описание Черниговской епархии. Чернигов, 1874. Кн. 5: Уезды Черниговский, Козелецкий, Суражский, Кролевецкий и Остерский. 443 с.

48. ЦДІАК (Центральний державний історичний архів України, м. Київ). Ф. 11 «Житомирський гродський суд». Оп. 1. Спр. 9. 2062 арк.

49. ЦДІАК. Ф. 21 «Кременецький гродський суд». Оп. 1. Спр. 83. 115 арк.

50. ЦДІАК. Ф. 21. Оп. 1. Спр. 94. 67 арк.

51. ЦДІАК. Ф. 25 «Луцький гродський суд». Оп. 1. Спр. 221. 1216 арк.

52. ЦДІАК. Ф. 25. Спр. 255. 1024 арк.

53. Яковенко Н. Матеріали до персонального складу канцелярій Волині, Наддніпрянщини та Східного Поділля (остання третина XVI - середина XVII століть). До джерел. Збірник наукових праць на пошану Олега Купчинського з нагоди його 70-річчя. Київ; Львів, 2004. Т. І. С. 320-357.

54. Яковенко Н. Українська шляхта з кінця XIV - до середини XVII століття. Волинь і Центральна Україна. Київ, 2008. 472 с.

55. AGAD (Archiwum Akt Dawnych w Warszawie). Metryka koronna. Sygn. 169. 528 k.

56. AGAD. Metryka koronna. Sygn. 180. 644 k.

57. AGAD. Metryka koronna. Sygn. 182. $535 \mathrm{k}$.

58. AGAD. Metryka koronna. Sygn. 185. $735 \mathrm{k}$.

59. AGAD. Metryka koronna. Sygn. 187. $247 \mathrm{k}$.

60. AGAD. Metryka koronna. Sygn. 188. 144 k.

61. AGAD. Metryka koronna. Sygn. 189. $783 \mathrm{k}$.

62. AGAD. Metryka koronna. Sygn. 191. $386 \mathrm{k}$.

63. AGAD. Tak zwana Metryka Litewska. Dz. V. Sygn. 1. 803 k.

64. AGAD. Tak zwana Metryka Litewska. Dz. V. Sygn. 4. 427 k.

65. Archiwum Narodowe w Krakowie. Archiwum Dzikowskie Tarnowskie. Zesp. 639. Sygn. 135. 940 k.

66. Augustyniak U. W służbie hetmana i Rzeczypospolitej. Klientela wojskowa Krzysztofa Radziwiłła (15851640). Warszawa, 2004. $398 \mathrm{~s}$

67. Baranowski B. Organizacja wojska Polskiego w latach trzydziestych i czterdziestych XVII wieku. Warszawa, 1957. $283 \mathrm{~s}$.

68. Biblioteka Polskiej Akademii Umiejętności i Polskiej Akademii Nauk w Krakowie. Rkps 263. $421 \mathrm{~s}$.

69. Biblioteka Polskiej Akademii Umiejętności i Polskiej Akademii Nauk w Krakowie. Rkps 264. $732 \mathrm{~s}$.

70. Boniecki A. Herbarz Polski. Warszawa, 1900. T. II. 387 s.

71. Boniecki A. Herbarz Polski. Warszawa, 1902. T. V. 400 s.

72. Boniecki A. Herbarz Polski. Warszawa, 1905. T. VIII. 396 s.

73. Boniecki A. Herbarz Polski. Warszawa, 1907. T. X. 391 s.

74. Boniecki A. Herbarz Polski. Warszawa, 1907. T. XI. 397 s.

75. Boniecki A. Herbarz Polski. Warszawa, 1908. T. XII. 400 s.

76. Boniecki A., Reiski A. Herbarz Polski. Warszawa, 1912. T. XV. 396 s.

77. Godziszewski W. Polska a Moskwa za Władysława IV (Rozprawy wydziału historyczno-filozoficznego. Ser. II. T. 42. Nr 6). Kraków, 1930. 72 s.

78. Metryka litewska. Rejestry podymnegoWielkiego Księstwa Litewskiego. Województwo wileńskie. Warszawa, 1989. $373 \mathrm{~s}$

79. Nisiecki K. Herbarz Polski. Lipsk, 1841. T. VI. 588 s.

80. Uruski S., Kosiński A., Włodarski A. Rodzina. Herbarz szlachty polskiej. Warszawa, 1914. T. XI. 380 s.

81. Uruski S., Kosiński A., Włodarski A. Rodzina. Herbarz szlachty polskiej. Warszawa, 1915. T. XII. 381 s.

82. Urzędnicy podolscy XIV-XVIII wieku. Spisy. Kórnik, 1998. 243 s. 
83. Volumina constitutionum. Warszawa, 2013. T. III: 1611-1640. Vol. 2: 1627-1640. 407 s.

84. Volumina constitutionum. Warszawa, 2015. T. IV: 1641-1668. Vol. 1: 1641-1658. $497 \mathrm{~s}$.

85. Źródła dziejowe. Warszawa, 1877. T.V: Lustracje królewszczyzn ziem Ruskich, Wołynia, Podola i Ukrainy z pierwszej połowy XVII wieku. $\mathrm{C}+226 \mathrm{~s}$.

\section{REFERENCES}

1. Arhiv Jugo-Zapadnoj Rossii, izdavaemyj Vremennoj komissiej dlja razbora drevnih aktov, uchrezhdennoj pri Kievskom, Podol'skom i Volynskom general-gubernatore. Ch. 4. T. 1. (1867). Kiev: Tipografia Imperatorskaho Universitieta sv. Vladimira. [in Russian].

2. Arhiv Jugo-Zapadnoj Rossii, izdavaemyj Vremennoj komissiej dlja razbora drevnih aktov, uchrezhdennoj pri Kievskom, Podol'skom i Volynskom general-gubernatore. Ch. 8. T. II (1894). Kiev: Tipografia Imperatorskaho Universitieta sv. Vladimira. [in Russian].

3. Voronchuk, I. (2012). Naselennia Volyni v XVI - pershii polovyni XVII st.: rodyna, domohospodarstvo, demohrafichni chynnyky. Kyiv: Feniks. [in Ukrainian].

4. Dzherela z istorii Natsionalno-vyzvolnoi viiny ukrainskoho narodu 1648-1658 rr. T. 1: 1648-1649 rr. Yu. Mytsyk [Ed.]. (2012). Kiev: PP „Foliant”. [in Ukrainian].

5. Instytut Rukopysu NBU (Instytut Rukopysu Natsionalnoi biblioteky Ukrainy im. V.I.Vernadskoho). F. I «Literaturni materialy». Spr. 4104. [in Ukrainian].

6. Instytut Rukopysu NBU. F. 81 «Levytskyi O.I». Spr. 28. [in Ukrainian].

7. Krykun, M. (2008). Bratslavske voievodstvo u XVI-XVIII stolittiakh. Statti i materialy. Lviv: Vydavnytstvo Ukrainskoho katolytskoho universytetu. [in Ukrainian].

8. Kulakovskyi, P. (2005). Borotba za spadshchynu: konflikt mizh Yanom ta Elzhbetoiu Pisochynskymy shchodo novhorod-siverskykh maietnostei. Sotsium. Almanakh sotsialnoi istorii. Kyiv: Instytut istorii Ukrainy. Vyp. 5. S. 127139. [in Ukrainian].

9. Kulakovskyi, P. (2006). Chernihovo-Sivershchyna u skladi Rechi Pospolytoi (1618-1648). Naukove vydannia. Kyiv: Tempora. [in Ukrainian].

10. Litvin, H. (2016). Shliakhta Kyivshchyny, Volyni ta Bratslavshchyny (1569-1648). Kyiv: Dukh i litera. [in Ukrainian].

11. LNNB (Lvivska natsionalna naukova biblioteka im. V. Stefanyka). F. 5 «Ossolinski». Spr. 4055. [in Ukrainian].

12. LNNB. F. 5. Spr. 4056. [in Ukrainian].

13. LNNB. F. 5. Spr. 4058. [in Ukrainian].

14. LNNB. F. 5. Spr. 4059. [in Ukrainian].

15. LNNB. F. 5. Spr. 4061. [in Ukrainian].

16. LNNB. F. 5. Spr. 4062. [in Ukrainian].

17. LNNB. F. 5. Spr. 4063. [in Ukrainian].

18. LNNB. F. 5. Spr. 4064. [in Ukrainian].

19. LNNB. F. 5. Spr. 4065. [in Ukrainian].

20. LNNB. F. 5. Spr. 4066. [in Ukrainian].

21. LNNB. F. 5. Spr. 4067. [in Ukrainian].

22. LNNB. F. 5. Spr. 4068. [in Ukrainian].

23. LNNB. F. 5. Spr. 4069. [in Ukrainian].

24. LNNB. F. 5. Spr. 4118. [in Ukrainian].

25. LNNB. F. 5. Spr. 4138. [in Ukrainian].

26. LNNB. F. 5. Spr. 4139. [in Ukrainian].

27. Mytsyk Yu. (1998). Muzhylovskyi Syluian. Polkovodtsi Viiska Zaporozkoho: Istorychni portrety. Kyiv: KM Academia. Vyp. 1. S. 221-226. [in Ukrainian].

28. Natsionalno-vyzvolna viina v Ukraini 1648-1657. Zbirnyk za dokumentamy aktovykh knyh. L.A. Sukhykh, V.V. Strashko [Ed.]. (2008). K.: ZAT «Vypol». [in Ukrainian].

29. Opis’ aktovoj knigi Kievskogo Central'nogo arhiva № 5: Kniga grodskaja zapisovaja, potochnaja i dekretovaja 1691, 94 i 95 gg. (1869). Kiev: Universitetskaja tipografija. [in Russian].

30. RHADA (Rossyiskyi hosudarstvennui arkhyv drevnykh aktov (h. Moskva). F. 79 «Snoshenyia Rossyy s Polshei». 1636. № 1a. [in Russian].

31. RHADA. F. 79. 1636. № 6. [in Russian].

32. RHADA. F. 79. 1638. № 9. [in Russian].

33. RHADA. F. 79. 1644. № 1. [in Russian].

34. RHADA. F. 79. 1647. № 1. [in Russian].

35. RHADA. F. 79. 1648. № 1. [in Russian].

36. RHADA. F. 210 «Razriadnыi prykaz». Novhorodskyi stol. Stlb.27. [in Russian].

36a. RHADA. F. 389 «Lytovskaia metryka». Op. 1. D. 110. [in Russian].

37. RHADA. F. 389. Op. 1. D. 200. [in Russian].

38. RHADA. F. 389. Op. 1. D. 201. [in Russian].

39. RHADA. F. 389. Op. 1. D. 214. [in Russian].

40. RHADA. F. 389. Op. 1. D. 218. [in Russian].

41. RHADA. F. 1473 «Pomestno-votchynnыe arkhyvы yuho-zapadnыkh zemel». Op. 1. D. 927. [in Russian].

42. Selianskyi rukh na Ukraini 1569-1647 rr. Zbirnyk dokumentiv i materialiv. (1993). Kyiv: Naukova dumka. [in Ukrainian]. 
43. Sobchuk V. (2012). Shliakhetskyi rid Lidykhivskykh u XV - seredyni XVII stolit. Kriz stolittia. Studii na poshanu Mykoly Krykuna z nahody 80-richchia. Lviv: Naukove tovarystvo im. Shevchenka. S. 92-126. [in Ukrainian]. 44. Ukrainska literatura XVII st.: Synkretychna pysemnist. Poeziia. Dramaturhiia. Beletrystyka. V. Krekoten' [Ed.] (1987). Kyiv: Naukova dumka. [in Ukrainian].

45. Ukrainski humanisty epokhy Vidrodzhennia. Antolohiia. Ch. 2. V. Nichyk [Ed.]. (1995). Kyiv: Naukova dumka; Osnovy. [in Ukrainian].

46. Universaly Ivana Mazepy 1687-1709. I. Butych [Ed.]. (2002). Kyiv; Lviv: Naukove tovarystvo im. Shevchenka. [in Ukrainian].

47. Filaret. (1874). Istoriko-statisticheskoe opisanie Chernigovskoj eparhii. Kn. 5: Uezdy Chernigovskij, Kozeleckij, Surazhskij, Kroleveckij i Osterskij. Chernigov: Gubernskaja tipografija. [in Russian].

48. TsDIAK (Tsentralnyi derzhavnyi istorychnyi arkhiv Ukrainy, m. Kyiv). F. 11 «Zhytomyrskyi hrodskyi sud».

Op. 1. Spr. 9. [in Ukrainian].

49. TsDIAK. F. 21 «Kremenetskyi hrodskyi sud». Op. 1. Spr. 83. [in Ukrainian].

50. TsDIAK. F. 21. Op. 1. Spr. 94. [in Ukrainian].

51. TsDIAK. F. 25 «Lutskyi hrodskyi sud». Op. 1. Spr. 221. [in Ukrainian].

52. TsDIAK. F. 25. Spr. 255. [in Ukrainian].

53. Yakovenko N. (2004). Materialy do personalnoho skladu kantseliarii Volyni, Naddniprianshchyny ta Skhidnoho

Podillia (ostannia tretyna KhVI - seredyna KhVII stolit). Do dzherel. Zbirnyk naukovykh prats na poshanu Oleha

Kupchynskoho z nahody yoho 70-richchia. T. I. Kyiv; Lviv: Prostir M. S. 320-357. [in Ukrainian].

54. Yakovenko, N. (2008). Ukrains'ka shliakhta z kintsia XIV - do seredyny XVII stolittia: Volyn' ta Tsentral'na

Ukraina. K.: Krytyka. [in Ukrainian].

55. AGAD (Archiwum Akt Dawnych w Warszawie). Metryka koronna. Sygn. 169. [in Polish].

56. AGAD. Metryka koronna. Sygn. 180. [in Polish].

57. AGAD. Metryka koronna. Sygn. 182. [in Polish].

58. AGAD. Metryka koronna. Sygn. 185. [in Polish].

59. AGAD. Metryka koronna. Sygn. 187. [in Polish].

60. AGAD. Metryka koronna. Sygn. 188. [in Polish].

61. AGAD. Metryka koronna. Sygn. 189. [in Polish].

62. AGAD. Metryka koronna. Sygn. 191. [in Polish].

63. AGAD. Tak zwana Metryka Litewska. Dz. V. Sygn. 1. [in Polish].

64. AGAD. Tak zwana Metryka Litewska. Dz. V. Sygn. 4. [in Polish].

65. Archiwum Narodowe w Krakowie. Archiwum Dzikowskie Tarnowskie. Zesp. 639. Sygn. 135. [in Polish].

66. Augustyniak, U. (2004). W służbie hetmana i Rzeczypospolitej. Klientela wojskowa Krzysztofa Radziwiłła

(1585-1640). Warszawa: Semper. [in Polish].

67. Baranowski, B. (1957). Organizacja wojska Polskiego w latach trzydziestych i czterdziestych XVII wieku. Warszawa: Wydawnictwo Ministerstwa Obrony Narodowej. [in Polish].

68. Biblioteka Polskiej Akademii Umiejętności i Polskiej Akademii Nauk w Krakowie. Rkps 263. [in Polish].

69. Biblioteka Polskiej Akademii Umiejętności i Polskiej Akademii Nauk w Krakowie. Rkps 264. [in Polish].

70. Boniecki, A. (1900). Herbarz Polski. T. II. Warszawa: skł. gł. Gebethner i Wolff. [in Polish].

71. Boniecki, A. (1902). Herbarz Polski. T. V. Warszawa: skł. gł. Gebethner i Wolff. [in Polish].

72. Boniecki, A. (1907). Herbarz Polski. T. VIII. Warszawa: skł. gł. Gebethner i Wolff. [in Polish].

73. Boniecki, A. (1907). Herbarz Polski. T. X. Warszawa: skł. gł. Gebethner i Wolff. [in Polish].

74. Boniecki, A. (1907). Herbarz Polski. T. XI. Warszawa: skł. gł. Gebethner i Wolff. [in Polish].

75. Boniecki, A. (1908). Herbarz Polski. T. XII. Warszawa: skł. gł. Gebethner i Wolff. [in Polish].

76. Boniecki, A., Reiski, A. (1912). Herbarz Polski. T. XIV. Warszawa: skł. gł. Gebethner i Wolff. [in Polish].

77. Godziszewski, W. (1930). Polska a Moskwa za Władysława IV (Rozprawy wydziału historyczno-filozoficznego.

Ser. II. T. 42. Nr 6). Kraków: skł. gł. w księg. Gebethnera i Wolffa. [in Polish].

78. Metryka litewska. Rejestry podymnegoWielkiego Księstwa Litewskiego. Województwo wileńskie. A. Rachuba

[Ed.]. (1989). Warszawa: Polskie Wydawnictwo Naukowe. [in Polish].

79. Nisiecki, K. (1841). Herbarz Polski. T. VI. Lipsk: Nakładem i drukiem Breikopfa Haertela. [in Polish].

80. Uruski, S., Kosiński, A., Włodarski, A. (1914). Rodzina. Herbarz szlachty polskiej. T. XI. Warszawa: skł. gł. Gebethner i Wolff. [in Polish].

81. Uruski S., Kosiński A., Włodarski A. (1915). Rodzina. Herbarz szlachty polskiej. Warszawa: skł. gł. Gebethner i Wolff. [in Polish].

82. Urzędnicy podolscy XIV-XVIII wieku. Spisy. E. Janas, W. Kłaczewski, J. Kurtyka, A. Sochacka [Ed.] (1998).

Kórnik: Biblioteka Kórnicka. [in Polish].

83. Volumina constitutionum. T. III: 1611-1640. Vol. 2: 1627-1640. S. Grodzicki, M. Kwiecień, A. Karabowicz

[Ed.] (2013). Warszawa: Wydawnictwo sejmowe. [in Polish].

84. Volumina constitutionum. T. IV: 1641-1668. Vol. 1: 1641-1658. S. Grodzicki, M. Kwiecień, K. Fokt [Ed.]

(2015). Warszawa: Wydawnictwo sejmowe. [in Polish].

85. Źródła dziejowe. T.V: Lustracje królewszczyzn ziem Ruskich, Wołynia, Podola i Ukrainy z pierwszej połowy XVII wieku. A. Jabłonowski [Ed.] (1877). Warszawa: skł. gł. w księg. Gebethnera i Wolffa. [in Polish]. 